\title{
Hydrologic Conditions in Rhode Island During Water Year 2014
}

Open-File Report 2015-1127 



\section{Hydrologic Conditions in Rhode Island During Water Year 2014}

By Richard J. Verdi and Roy S. Socolow

Open-File Report 2015-1127 


\title{
U.S. Department of the Interior SALLY JEWELL, Secretary
}

\section{U.S. Geological Survey \\ Suzette M. Kimball, Acting Director}

\author{
U.S. Geological Survey, Reston, Virginia: 2015
}

For more information on the USGS - the Federal source for science about the Earth, its natural and living resources, natural hazards, and the environment-visit http://www.usgs.gov/ or call 1-888-ASK-USGS.

For an overview of USGS information products, including maps, imagery, and publications, visit http://www.usgs.gov/pubprod/.

Any use of trade, firm, or product names is for descriptive purposes only and does not imply endorsement by the U.S. Government.

Although this information product, for the most part, is in the public domain, it also may contain copyrighted materials as noted in the text. Permission to reproduce copyrighted items must be secured from the copyright owner.

Suggested citation:

Verdi, R.J., and Socolow, R.S., 2015, Hydrologic conditions in Rhode Island during water year 2014: U.S. Geological Survey Open-File Report 2015-1127, 8 p., http://dx.doi.org/10.3133/ofr20151127.

ISSN 2331-1258 (online) 


\section{Contents}

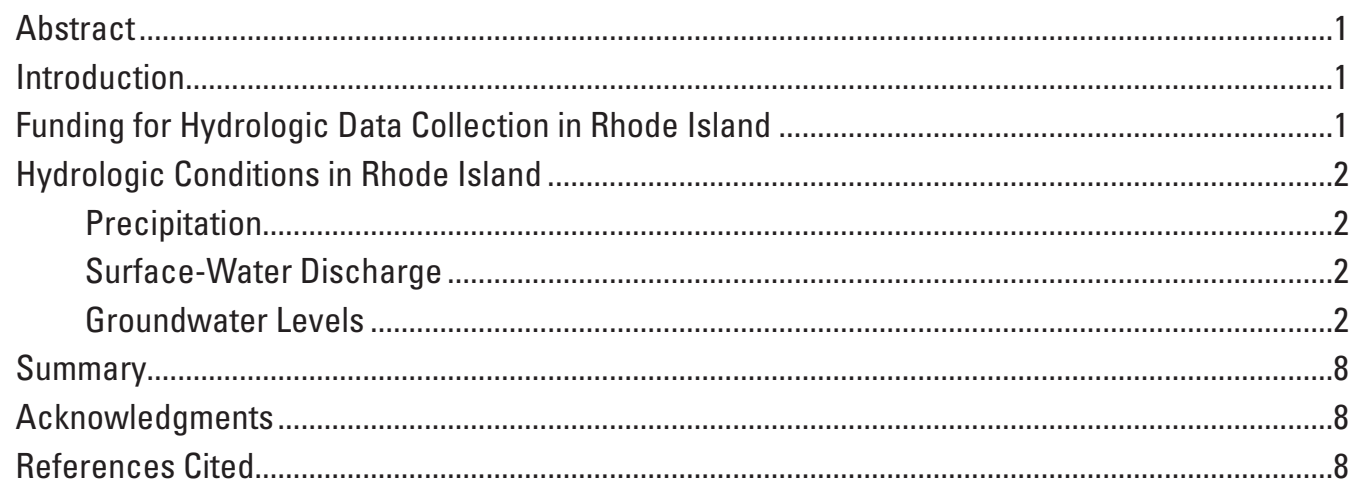

\section{Figures}

1. Map and data of Rhode Island monitoring stations used in assessing hydrologic conditions in 2014

2. $A-D$, Graphs showing cumulative precipitation for water year 2014 relative to normal cumulative precipitation in selected locations in Rhode Island ............................4

3. $A-D$, Discharge hydrographs for four representative streams in Rhode Island for water year 2014 ........................................................................................................ 5

4. $A-D$, Groundwater hydrographs for four representative wells in Rhode Island

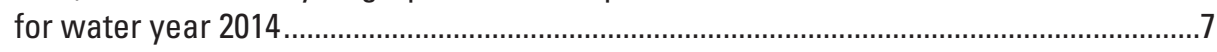

\section{Tables}

1. Mean annual discharge of selected streams for water years 2014,2013 , and for the period of record.

2. Record-low minimum monthly mean discharges during water year 2014 compared with the period of record. 


\section{Conversion Factors}

Inch/Pound to International System of Units

\begin{tabular}{lll}
\hline \multicolumn{1}{c}{ Multiply } & By & \multicolumn{1}{c}{ To obtain } \\
\hline inch (in.) & Length & \\
foot (ft) & 2.54 & centimeter $(\mathrm{cm})$ \\
\hline & 0.3048 & meter $(\mathrm{m})$ \\
\hline cubic foot per second $\left(\mathrm{ft}^{3} / \mathrm{s}\right)$ & Flow rate & \\
\hline
\end{tabular}

\section{Datum}

Vertical coordinate information is referenced to the North American Vertical Datum of 1988 (NAVD 88).

Horizontal coordinate information is referenced to the North American Datum of 1983 (NAD 83).

\section{Abbreviations}

$\begin{array}{ll}\text { ADR } & \text { annual data report } \\ \text { CBR } & \text { Collection of Basic Records [Program] } \\ \text { NSIP } & \text { National Streamflow Information Program } \\ \text { NWIS } & \text { National Water Information System } \\ \text { USGS } & \text { U.S. Geological Survey }\end{array}$




\title{
Hydrologic Conditions in Rhode Island During Water Year 2014
}

\author{
By Richard J. Verdi and Roy S. Socolow
}

\begin{abstract}
Hydrologic data and conditions throughout Rhode Island during water year 2014 are presented in this report. Stream discharge and groundwater level conditions varied geographically across the State. Ten streamgages reached record-low minimum monthly mean discharges during the year, and a record-high maximum groundwater level was observed at one groundwater well.
\end{abstract}

\section{Introduction}

Prior to 1960 , hydrologic data collected by the U.S. Geological Survey (USGS) in Rhode Island were published in various water-supply papers and included waterrelated data collected by the USGS during a water year. ${ }^{1}$ In 1961, a series of annual reports titled "Water-Resources Data for Rhode Island" was introduced; those reports contained only surface-water data. In 1964, a similar report was introduced for the purpose of publishing water-quality data. In 1975, surface-water data, water-quality data, and groundwater-level data were published in a single volume annual report. Formal publication of the annual report series was discontinued at the end of water year 2004. Reports describing data collected during water years 2005 through 2013 are available as site data sheets from the USGS annual water data report Web site (U.S. Geological Survey, 2015a), which facilitates the retrieval of reports for stations throughout the United States. Beginning with water year 2014, reports describing data collected during the water year are being published as annual water summaries and are available from the USGS National Water Information System (NWIS; U.S. Geological Survey, 2015g). Current and historical data, including site information, daily values, statistics, and field measurements, are available for all monitoring stations on the USGS NWIS (U.S. Geological Survey, 2015g).

In this report, monitoring station refers to a streamgage, groundwater well, or precipitation gage. Instantaneous

${ }^{1} \mathrm{~A}$ water year is the 12-month period beginning October 1 and ending September 30. It is designated by the year in which it ends. time-series data for the past 10 to 15 years are available for many characteristics, including gage height, discharge, water temperature, specific conductance, and other parameters. As a result of the evolution of electronic data loggers, computer systems have made it possible to store and provide access to such data for many USGS monitoring stations. These instantaneous time-series data are typically recorded at intervals of 60 minutes or less and are the basis for computations of daily values for discharge, water level, and other hydrologic variables (U.S. Geological Survey, 2014).

This report summarizes hydrologic data and conditions at representative well and stream sites throughout Rhode Island for water year 2014. Precipitation and water-level data for select sites are shown graphically. Discharge data for select sites are shown graphically and listed in tables.

\section{Funding for Hydrologic Data Collection in Rhode Island}

Funding to provide hydrologic data to the public primarily comes from four sources: (1) the USGS Cooperative Water Program in which the USGS, State, local, and municipal agencies share in the costs of the monitoring stations; (2) Federal, State, and local agencies and private entities without cost sharing; (3) the USGS National Streamflow Information Program (NSIP); and (4) the USGS Collection of Basic Records (CBR) Program. The USGS Cooperative Water Program funds most of the monitoring stations in Rhode Island through cost-sharing agreements with several State agencies and local, county, and municipal governments. The NSIP provides some Federal funding for streamgages with one or more of the following critical interests: interstate and international waters, flood forecasts, large river-basin outflows, sentinel watersheds, and water quality. The CBR Program provides some Federal funding for a basic network of groundwater monitoring wells across the Nation.

During water year 2014, funding was received for the collection of hydrologic data from 35 continuousdischarge streamgages, 6 continuous-groundwater stations, and 27 (including the 6 continuous stations) month-end 
groundwater-level stations in the USGS Climate Response Network. Real-time data for all of the continuous-record stations are available from the USGS NWIS (U.S. Geological Survey, 2015f). The locations of the monitoring streamgages and groundwater stations referenced in this report are identified in figure 1 .

\section{Hydrologic Conditions in Rhode Island}

The hydrologic conditions in Rhode Island during water year 2014 are described below, and comparisons are made to normal conditions. Normal conditions are defined in this report as climate normals (1981-2010 average) for precipitation, the long-term average for the period of record for surface water, or the median for the period of record for groundwater. Analyses of data are made for precipitation, surface-water discharge, and groundwater levels.

\section{Precipitation}

The graphs in figures $2 A-D$ show cumulative precipitation for water year 2014 relative to normal cumulative precipitation in four areas of Rhode Island. The data presented in these figures were provided by the National Oceanic and Atmospheric Administration (2015) ACIS database.

Lower than normal precipitation conditions from the end of water year 2013 continued into the 2014 water year. Precipitation at Providence (fig. 2C) and Kingston (fig. 2A) started the year below normal and continued similarly through the winter months and into late March. Near normal conditions in spring and early summer continued through July. However, conditions were below normal once again from August 1 through the end of the water year. Cumulative precipitation at Woonsocket (fig. $2 D$ ) and North Foster (fig. 2B) was below normal during the entire water year.

The effects of numerous consecutive months of lower than normal precipitation were recorded at streamgage locations throughout the State. Nine of the locations in the long-term streamgage network reported record-low minimum monthly mean discharges. These data are discussed in the "Surface-Water Discharge" section.

\section{Surface-Water Discharge}

Discharge hydrographs for four representative streams in Rhode Island are shown in figures $3 A-D$. Each hydrograph shows the monthly mean discharge for water year 2014 relative to the monthly maximum, minimum, and mean discharges for the period of record for the station. Table 1 presents mean annual discharge for water years 2014 and 2013 (for comparison), expressed in cubic feet per second and as a percentage of the mean annual average for the period of record, for the four representative streams.
Monthly mean discharge in streams varied from below normal to above normal in Rhode Island during water year 2014 (figs. 3A-D). Annual rates of mean discharge in streams varied from below normal to about normal throughout the State (table 1). Conditions were mostly below normal throughout the State in the fall and early winter months leading up to January. From January through June, conditions ranged from about normal to above normal, with the months of April and May being the only 2 months when conditions at all four streams were above normal. After June, conditions steadily declined through the end of the water year with 9 of the 22 long-term (more than 20 years of continuous record) streamgages in the State recording new minimum monthly mean discharges (table 2). Several consecutive months of below normal precipitation contributed to many streams experiencing periods of record-low minimum monthly mean discharges. For example, a new minimum monthly mean discharge was recorded at the Branch River at Forestdale, RI streamgage (01111500; U.S. Geological Survey, 2015d) during September 2014. The new record of 9.26 cubic feet per second $\left(\mathrm{ft}^{3} / \mathrm{s}\right)$ exceeds the previous record of $16.4 \mathrm{ft}^{3} / \mathrm{s}$ set in 2002. A second example is Pawcatuck River at Westerly, RI streamgage (01118500; U.S. Geological Survey, 2015e) where a new minimum monthly mean discharge was recorded during September 2014. The new record of $55.1 \mathrm{ft}^{3} / \mathrm{s}$ exceeds the previous record of $65.7 \mathrm{ft}^{3} / \mathrm{s}$ set in 1964 .

\section{Groundwater Levels}

Groundwater hydrographs for four representative wells in Rhode Island are shown in figures $4 A-D$. Representative wells are located in sand and gravel aquifers in glaciated regions. Each hydrograph shows the discrete month-end water level relative to the maximum, minimum, and monthly median water levels for the period of record at that site.

Groundwater levels across the State ranged from below normal to above normal. A new maximum monthly groundwater level was measured at the Coventry observation well (RI-COW 411) in March (fig. 4B; U.S. Geological Survey, 2015c). The new record of 17.20 feet below land surface exceeds the previous record of 17.45 feet below land surface set in 2010. The large increase in water levels from February to March is attributed to a precipitation event prior to the measurement on April 1. Precipitation in Coventry totaled 5.10 inches from March 29 through April 1 (National Oceanic and Atmospheric Administration, 2015). Similar month-tomonth water-level rises have occurred at this location several times in the past. Daily mean groundwater levels for the six continuous-recording wells in the State are available as site data sheets (U.S. Geological Survey, 2015a). Month-end water levels, water-level statistics, and well characteristics for the 27 wells in the State are part of the Climate Response Network (U.S. Geological Survey, 2015b). 


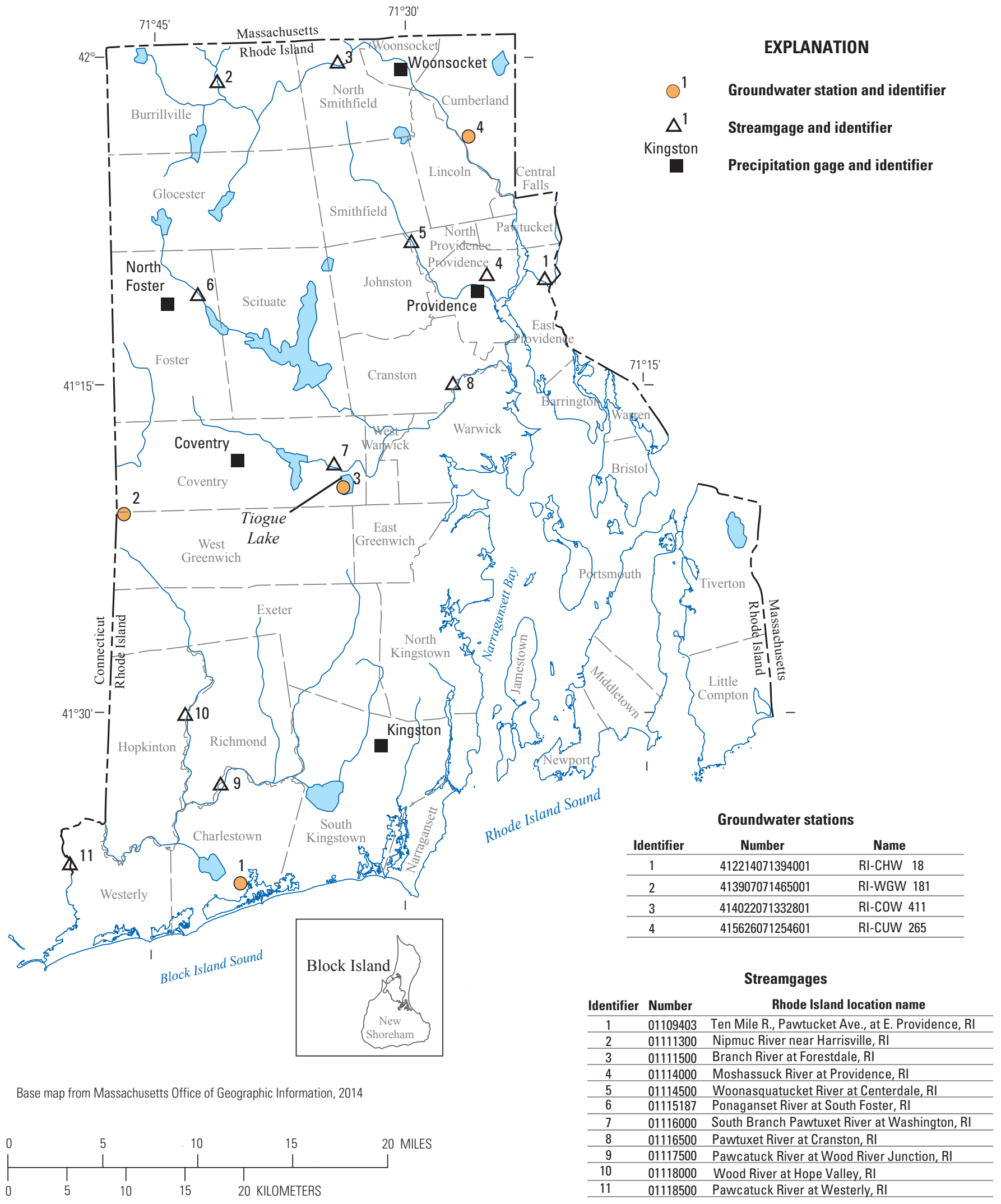

Figure 1. Rhode Island monitoring stations used in assessing hydrologic conditions in 2014. 
A. Accumulated precipitation, Kingston, Rhode Island

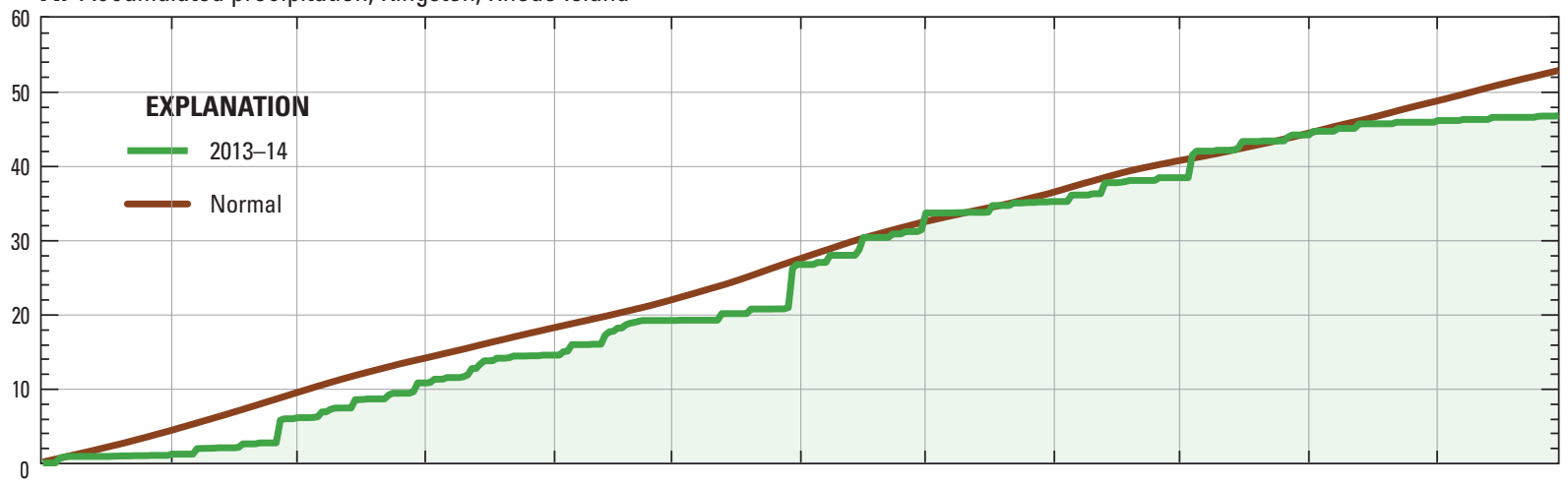

B. Accumulated precipitation, North Foster $1 \mathrm{E}$, Rhode Island

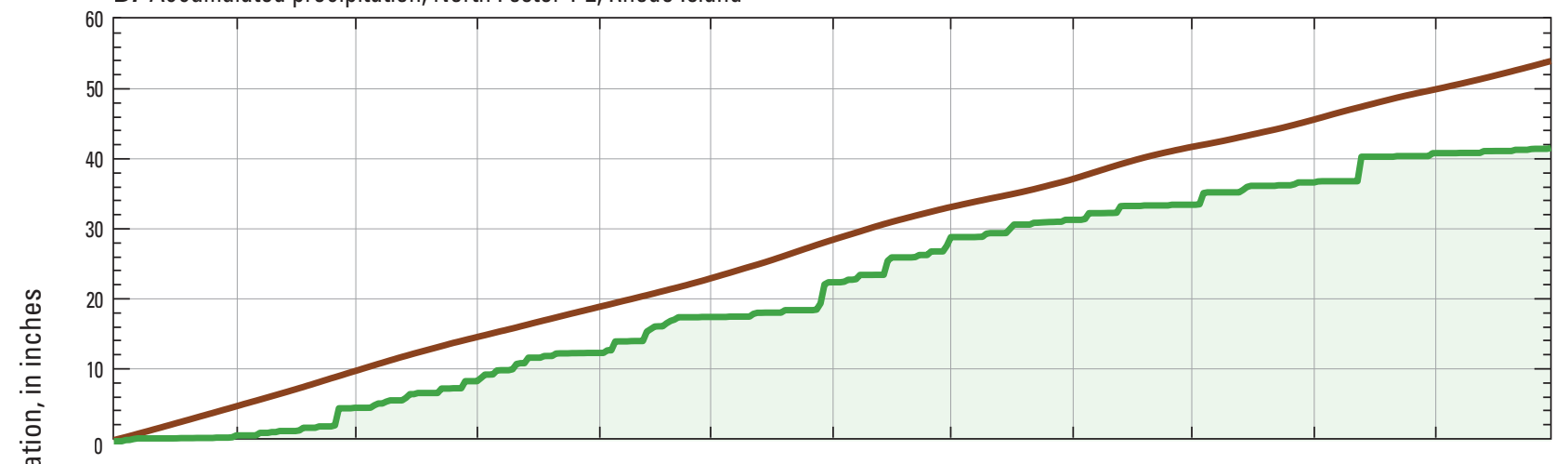

C. Accumulated precipitation, Providence area, Rhode Island

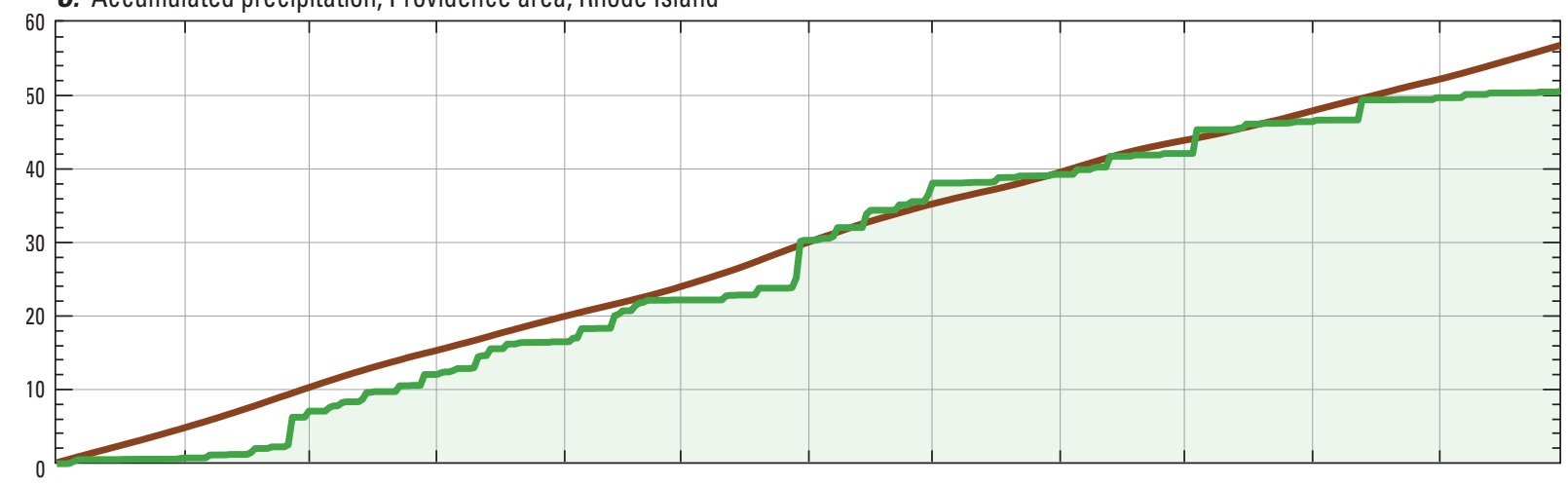

D. Accumulated precipitation, Woonsocket, Rhode Island

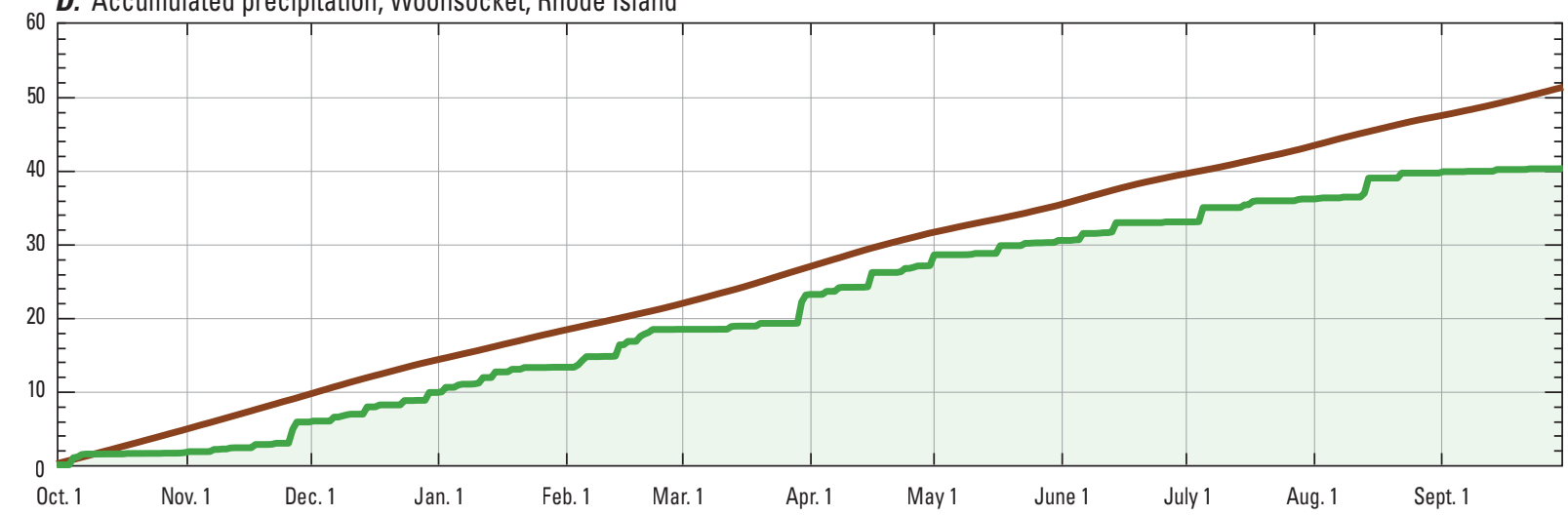

Figure 2. $A-D$, Cumulative precipitation for water year 2014 relative to normal cumulative precipitation in selected locations in Rhode Island. Normal conditions are defined in this report as climate normals (1981-2010 average) for precipitation. Accumulated precipitation is measured at National Oceanic and Atmospheric Administration stations. 

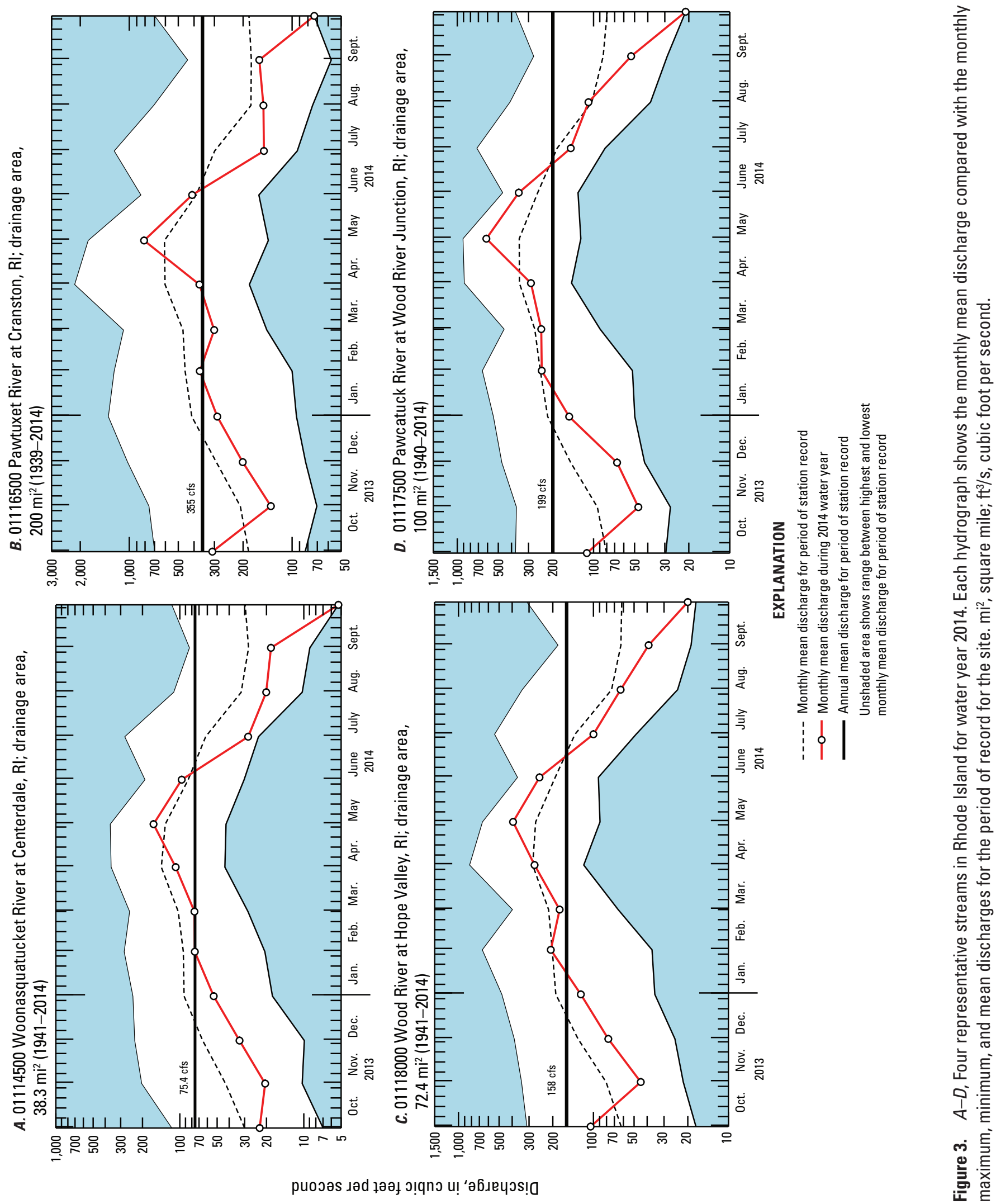

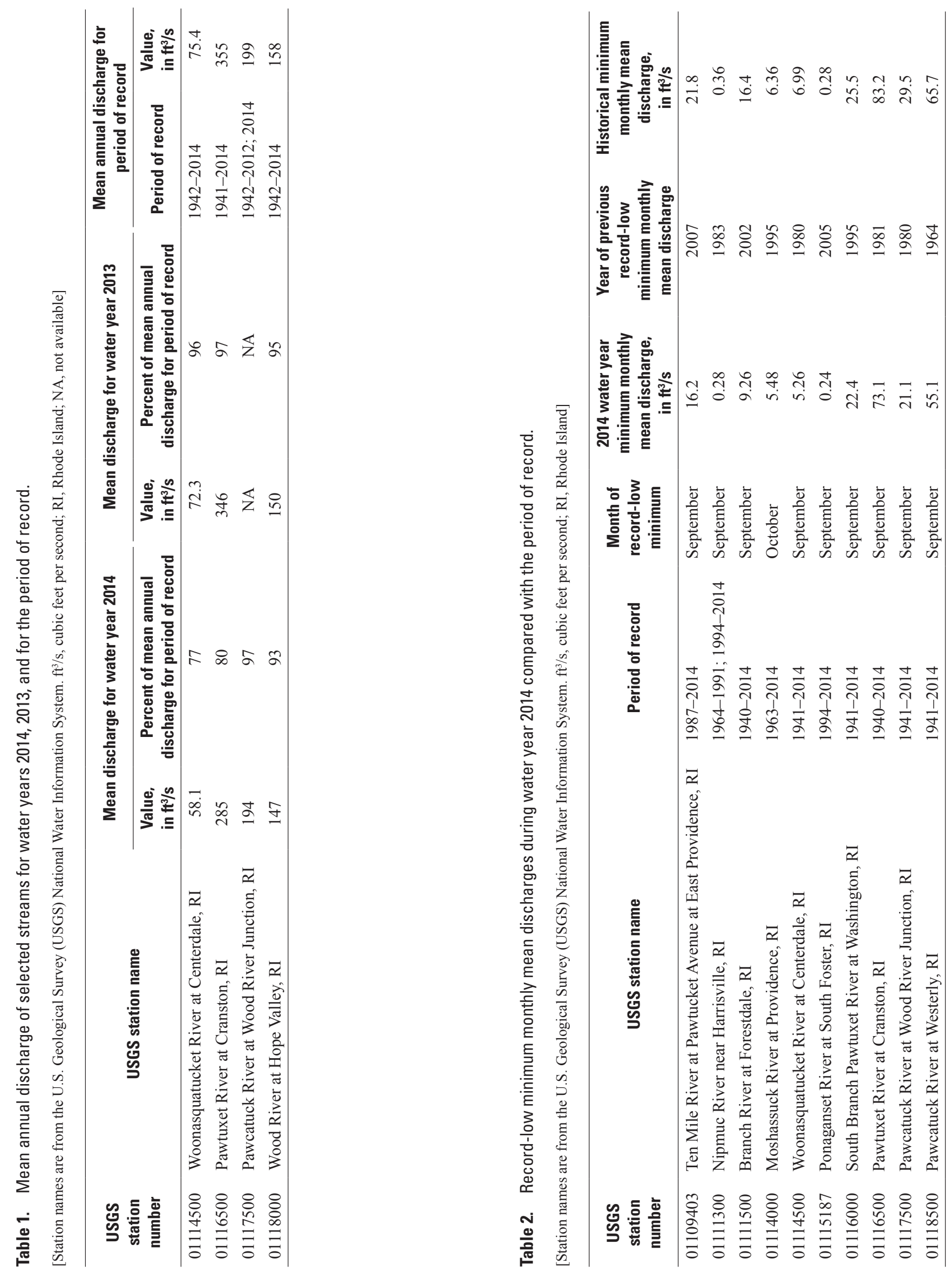

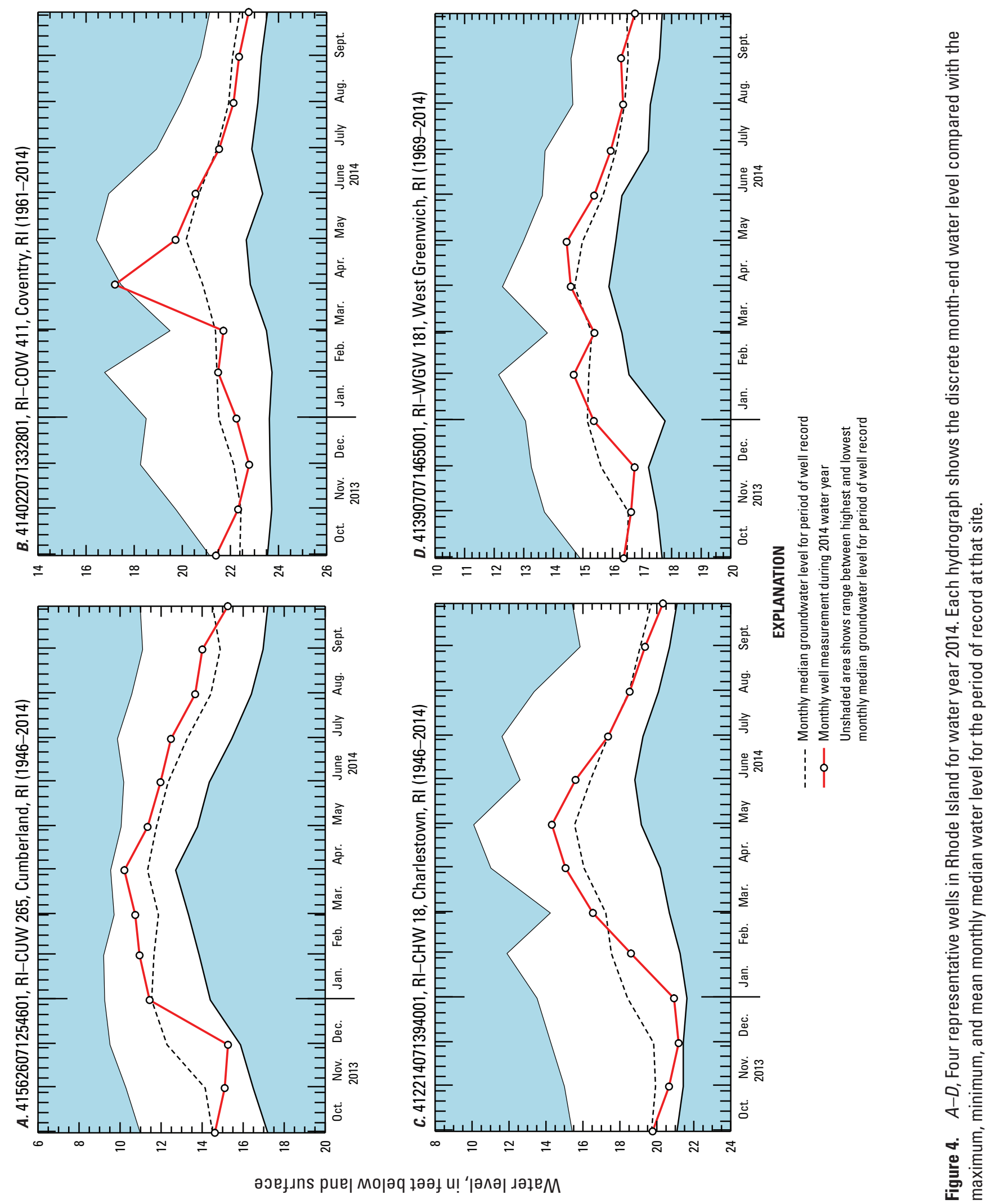


\section{Summary}

Hydrologic conditions varied geographically across Rhode Island during water year 2014. Annual cumulative precipitation averaged mostly below normal to about normal throughout the State. Stream discharges varied throughout the year with 10 sites reaching record-low minimum monthly mean discharges. Groundwater levels ranged from below normal to above normal with one site recording a new maximum water level during the year.

\section{Acknowledgments}

The authors acknowledge the contributions of senior hydrographers Linda Comeau and Lance Ramsbey and hydrographers Robert Bradley, Christopher Bruet, Josh Combs, Emilie Nobles, and Steve O'Brien of the U.S. Geological Survey (USGS) Hydrologic Surveillance Unit in Northborough, Massachusetts, for their efforts in data collection and records computations. Thanks are extended to Rick Kiah and Dave Armstrong of the USGS for their technical reviews of this report.

\section{References Cited}

National Oceanic and Atmospheric Administration, 2015, xmACIS2: National Oceanic and Atmospheric Administration database, accessed April 23, 2015, at http://xmacis.rcc-acis.org/.

U.S. Geological Survey, 2014, Instantaneous data archiveIDA: U.S. Geological Survey Web site, accessed April 2015 at http://ida.water.usgs.gov/ida/index_usgs.cfm.
U.S. Geological Survey, 2015a, Annual water data reports: U.S. Geological Survey Web site, accessed April 2015 at http://wdr.water.usgs.gov/.

U.S. Geological Survey, [2015]b, Rhode Island climate response network: U.S. Geological Survey Groundwater Watch Web page, accessed April 2015 at http:/groundwaterwatch.usgs.gov/NetMapT1L2.asp?ncd=crn\&sc=44.

U.S. Geological Survey, [2015]c, Site number 412214071394001-RI-CHW 18: U.S. Geological Survey Groundwater Watch Web page, accessed April 2015 at http://groundwaterwatch.usgs.gov/AWLSites. asp?S=412214071394001\&ncd=awl.

U.S. Geological Survey, [2015]d, USGS 01111500 Branch River at Forestdale, RI: U.S. Geological Survey National Water Information System Web page, accessed April 2015 at http://waterdata.usgs.gov/ma/nwis/uv?site_no $=01111500$.

U.S. Geological Survey, [2015]e, USGS 01118500 Pawcatuck River at Westerly, RI: U.S. Geological Survey National Water Information System Web page, accessed April 2015 at http://waterdata.usgs.gov/nwis/uv/?site_no $=01118500$.

U.S. Geological Survey, [2015]f, USGS current water data for Rhode Island: U.S. Geological Survey National Water Information System Web page, accessed April 2015 at http://waterdata.usgs.gov/ri/nwis/rt/.

U.S. Geological Survey, [2015]g, USGS water data for Rhode Island: U.S. Geological Survey National Water Information System Web page, accessed April 2015 at http://waterdata. usgs.gov/ri/nwis/nwis. 
For more information concerning this report, contact: Director, New England Water Science Center U.S. Geological Survey 10 Bearfoot Road Northborough, MA 01532 dc_nweng@usgs.gov or visit our Web site at: http://ma.water.usgs.gov http://ri.water.usgs.gov

Publishing support by: The Pembroke Publishing Service Center. 


\section{$\frac{1}{4}$}

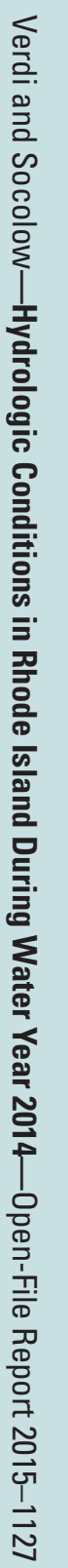

8 Printed on recycled paper 